Article

\title{
Sustainability Performance of Organization: Mediating Role of Knowledge Management
}

\author{
I Ketut Setia Sapta ${ }^{1, *}$, I Nengah Sudja ${ }^{1}$, I Nengah Landra ${ }^{1}$ and Ni Wayan Rustiarini ${ }^{2}$ (D) \\ 1 Management Department, Faculty of Economics and Business, Universitas Mahasaraswati Denpasar, \\ Denpasar 80233, Indonesia; sudja@unmas.ac.id (I.N.S.); nengahlandra@unmas.ac.id (I.N.L.) \\ 2 Accounting Department, Faculty of Economics and Business, Universitas Mahasaraswati Denpasar, \\ Denpasar 80233, Indonesia; rusti_arini@unmas.ac.id \\ * Correspondence: ketutsetiasapta@unmas.ac.id
}

Citation: Sapta, I Ketut Setia, I Nengah Sudja, I Nengah Landra, and Ni Wayan Rustiarini. 2021.

Sustainability Performance of Organization: Mediating Role of Knowledge Management. Economies 9: 97. https://doi.org/10.3390/ economies 9030097

Academic Editor: Ralf Fendel

Received: 29 April 2021

Accepted: 14 June 2021

Published: 27 June 2021

Publisher's Note: MDPI stays neutral with regard to jurisdictional claims in published maps and institutional affiliations.

Copyright: (c) 2021 by the authors. Licensee MDPI, Basel, Switzerland. This article is an open access article distributed under the terms and conditions of the Creative Commons Attribution (CC BY) license (https:// creativecommons.org/licenses/by/ $4.0 /)$.

\begin{abstract}
Research about sustainable performance and its impact on the organization's economic, social, and environmental development has attracted the attention of many scholars. However, the research investigating the relationship between sustainable performance from traditional organizations based on local culture is still underdeveloped. This study aimed to examine the relationship among organizational culture and leadership styles with knowledge management and sustainable performance. Moreover, this study investigates knowledge management's role as a mediating variable in the relationship between organizational culture, leadership style, and sustainable performance. This study adopted a quantitative approach using the purposive sampling method with a questionnaire distributed to 99 respondents in Bali Province, Indonesia. The analysis technique was SEM-PLS. The results revealed that organizational culture and transformational leadership have significant effects on knowledge management. This study also proves that knowledge management mediates the relationship between organizational culture and sustainable performance, as well as the relationship between leadership style and sustainable performance. Theoretically, this study confirms the knowledge-based theory about knowledge management practices and sustainability performance. The present study also highlights the characteristics of organizational culture in traditional organizations and the effectiveness of transformational leadership to achieve sustainable organizational performance. Practically, the results provide insights to aid governments and regulators in continuously implementing knowledge management to achieve sustainable performance.
\end{abstract}

Keywords: organizational culture; Subak; transformational leadership; Tri Hita Karana; Indonesia

\section{Introduction}

The sustainability of an organization is a strategic issue in sustainable development. A company will achieve sustainable development if it pays attention to the balance of three aspects, namely economic, social, and environmental. Therefore, companies should prioritize financial and economic goals, pay attention to social benefits, and preserve the environment. Furthermore, sustainable performance requires that every organization meet the presents needs without sacrificing those of future generations' needs (Schaltegger et al. 2015; Baumgartner and Rauter 2017).

One of the efforts that companies make to achieve sustainable performance is through increasing knowledge management. Several works in the literature works have recognized knowledge as the main asset of a business (Obeidat et al. 2016; Heisig et al. 2016), with some works even claiming that it is the only source of sustainable competitive advantage (Mahdi et al. 2019; Torres et al. 2018; de Guimarães et al. 2018). However, knowledge management's mediating role has not been adequately investigated (Zheng et al. 2013). Given that knowledge is a construct that cannot be observed and measured directly, it can only be identified through observable outputs (Stehr 1992; Hunter 2017), such as 
performance. Therefore, research to explore knowledge management's role as a mediating factor is essential to achieve sustainable organizational performance.

One challenge in implementing knowledge management into organizational processes is an unsupportive organizational culture (Adeinat and Abdulfatah 2019; Lozano et al. 2013). This condition causes inconsistencies in research results related to the influence of organizational culture on knowledge management practice. On the one hand, organizational culture strongly supports knowledge management's successful practice (Al Saifi 2015; Lee et al. 2016). However, on the other hand, organizational culture often clashes with knowledge management (Bedford 2013). Moreover, organizational culture is a significant barrier to success in the knowledge management process (Ajmal and Koskinen 2008; Chang and Lin 2015). Therefore, a study that examines organizational culture and leadership style in supporting knowledge management and sustainable performance would be essential and exciting.

This study aimed to examine the relationships among organizational culture and leadership styles with knowledge management and sustainable performance. Moreover, the study investigates knowledge management's role as a mediating variable in the relationship between organizational culture, leadership style, and sustainable performance. Therefore, this study attempts to answer the following questions:

Q1. Does organizational culture affect knowledge management and sustainable performance?

Q2. Does leadership style affect knowledge management and sustainable performance?

Q3. Does knowledge management affect sustainable performance?

Theoretically, this study confirms the knowledge-based theory about knowledge management practices and sustainability performance. This study also highlights the characteristics of organizational culture in traditional organizations and the effectiveness of transformational leadership styles to achieve sustainable organizational performance. It is additionally important considering that not many studies have examined traditional organization's performance, for example, is Subak. Most empirical studies only identify modern business-oriented organizations (Bogoviz et al. 2019; Matinaro and Liu 2017; Linnenluecke and Griffiths 2010). Moreover, as a traditional organization, Subak is vulnerable to environmental, social, and economic changes as consequences of sustainable development (Wiguna and Surata 2008; Kieninger et al. 2011).

Practically, this study's results provide a framework and insights to aid regulators in continuously implementing knowledge management to achieve sustainable performance in the Subak organization. Furthermore, as a world heritage (Surata and Vipriyanti 2018), Subak supports agricultural development and improves the economy. Thus, the results of this study provide recommendations for the government to maintain the sustainability performance of Subak, particularly in the current area of modernization.

\section{Literature Review and Hypothesis Development}

This theory is based on the knowledge-based theory. This view emphasizes the importance of knowledge as a firm's sustainable competitive advantage (Mahdi et al. 2019; Torres et al. 2018; de Guimarães et al. 2018). Knowledge is the only long term competitive advantage possessed by a company (Ikujirō Nonaka and Takeuchi 2007), and it includes contextual information, framed experiences, and expert insights (Jennex 2015; Omotayo 2015). Thus, companies must produce, integrate, and distribute knowledge within the organization (Valmohammadi and Ahmadi 2015; Cano-Kollmann et al. 2016). The knowledge-based human resource approach is deliberately designed to improve organizational knowledge (Kianto et al. 2017).

According to the knowledge-based view, knowledge is one of the organization's strategic plans to ensure organizational performance. Organizations will create core competencies if they can develop new knowledge (Nonaka and Toyama 2015). The basic premise of this concept is to use knowledge as the primary source and production input. Therefore, knowledge-based companies will engage in more accurate resource management 
(Gu et al. 2017; Kengatharan 2019). Knowledge management is a series of processes that aim to convert data into knowledge or valuable information for advancing the organization (Nonaka and Toyama 2015). These processes include creating, acquiring, storing, sharing, and using knowledge (Valmohammadi et al. 2019; Cano-Kollmann et al. 2016). Furthermore, competitive advantage is generated from the knowledge possessed and developed by organizational members (Mahdi et al. 2019; Huang et al. 2015). Agile organizational management can well manage knowledge to produce quality knowledge. Thus, it can be concluded that knowledge management affects the quality of decisions made and actions taken (Abubakar et al. 2019).

The organization can get the benefits by adopting or implementing the knowledge management practices to create methods or innovations, business models, and strategic positions in industry (Al Saifi 2015; Iqbal et al. 2019; Koohang et al. 2017; Arsawan et al. 2021; Farooq 2019). In terms of sustainable performance, knowledge-based companies have good opportunities to generate high returns in a sustainable manner (Kianto et al. 2017). The creation of new knowledge and methods can benefit the organization and society, environment, and economy (Lopes et al. 2017; Valmohammadi et al. 2019). Knowledge management plays an essential role in creating organizational excellence through a process of innovation, learning, and decision making (Jiménez et al. 2020; Rasula et al. 2012; Adeinat and Abdulfatah 2019).

One critical factor influencing the knowledge management process is organizational culture. Some previous studies stated that organizational culture supports knowledge management practices (Chang and Lin 2015; Abubakar et al. 2019). However, some other researchers have also revealed that organizational culture often clashes with knowledge management (Bedford 2013). Organizational culture is a significant barrier to success in the knowledge management process (Ajmal and Koskinen 2008; Chang and Lin 2015). Some of these obstacles are related to experts' limitations, training, and lack of a creative culture supporting the learning process and producing knowledge (Adeinat and Abdulfatah 2019). In the context of Subak organizations, Tri Hita Karana is a traditional life philosophy in Bali which determines the local culture and impacts the organization. Tri Hita Karana emphasizes that happiness comes from the harmony between humans and God, humans and other humans, as well as humans and environment (Roth and Sedana 2015; Sapta et al. 2016). Therefore, Tri Hita Karana supports the implementation of knowledge management without any conflict with the cultural values. Previous studies have shown that organizational culture facilitates the organizations' knowledge development (Ajmal and Helo 2010; Sheikhalizadeh and Piralaiy 2017; Fernandes 2018; Nurkholis et al. 2020). Thus, the hypothesis is formulated as follows:

Hypothesis 1 (H1). Organizational culture has a positive effect on knowledge management.

The leadership style dramatically determines the success of knowledge management. Each leadership style has a different impact on the implementation of knowledge management (Donate and Sánchez de Pablo 2015). Leadership is a driving factor for organizations towards change (Stankevičiūtè and Savanevičienè 2021). A leader's existence should be a symbol which provides solutions to the organizational problems and positively impacts the organizational development (Yadav et al. 2019). Based on the transformational leadership perspective, the leader's behaviors accelerate the innovative thinking to improve both employee and organizational performance. In addition, a leader must motivate or encourage his staff to improve their creativity when working (Kark et al. 2018; Feng et al. 2018; Afsar and Umrani 2020). Thus, transformational leaders greatly affect the implementation of knowledge management to improve the organizational performance (Birasnav 2014; Feranita et al. 2020). Previous findings have presented that transformational leadership determines the organizational learning and organizational performance (Afsar et al. 2019; Park and Kim 2018; Yadav et al. 2019). Thus, the hypothesis is formulated as follows: 
Hypothesis 2 (H2). Transformational leadership style has a positive effect on knowledge management.

Organizational sustainability cannot be separated from organizational culture (Islam et al. 2017). Culture is a pattern of thoughts, feelings, and actions of one social group to be differentiated from the other social groups (Hofstede 2001). Organizational culture is also a shared perception belonging to each organization member and becomes a shared meaning system (Robbins and Judge 2016). The corporate culture literature reveals that organizational culture is the main attribute to improve performance (Linnenluecke and Griffiths 2010; Tseng et al. 2018; Jabbour and de Sousa Jabbour 2016). Organizations need to align the corporate strategic decisions with the organizational culture to achieve sustainable development (Baumgartner 2014). Organizations start adopting the strategies and policies to achieve the sustainable development goals. Organizations commonly change their organizational culture to align with the sustainable development (Feng et al. 2017; Linnenluecke and Griffiths 2010). Companies must also emphasize the cultural transformation in creating the organizational performance sustainability (Islam et al. 2017). However, not all cultural changes can direct the organizations toward sustainable development (Linnenluecke and Griffiths 2010). In the perspective of Subak organizational culture, there are three main strengths underlying the organizational activities consisting the organizational structure simplicity, cooperation-based working system, and balance concept between nature, humans, and God (Roth and Sedana 2015). Balance concept is believed maintaining the sustainability of human life on earth. Thus, the hypothesis is formulated as follows:

Hypothesis 3 (H3). Organizational culture has a positive effect on sustainability performance.

Leadership is a person's ability to influence others to do or not to do something in accordance with his will in achieving the predetermined goals (Fairman and Mackenzie 2015; Dugan 2017). This ability is used to influence and mobilize the subordinates who are passionate with the work, willing to cooperate, and have the discipline to achieve specific goals in organized manners (Ikeda and Marshall 2016). The leadership aspect is a special requirement to direct the organization to achieve its sustainable performance (Ferdig 2007). A leader must provide vision and inspire his subordinates, to responsibly and consistently demonstrate their success (Anning-Dorson 2018). Therefore, sustainable performance requires leaders who are committed to take these actions (Parkin 2010; Jiang et al. 2017). Transformational leadership is a leadership style considered appropriate to accommodate these needs. Leaders should always increase their awareness and motivate their subordinates to improve their performance to achieve the organizational goals (Jiang et al. 2017; Cavazotte et al. 2013; Yahaya and Ebrahim 2016). Waldman and Siegel (2008) revealed that despite the scarcity of research discussing this topic, transformational leaders' intellectual stimulation competence is considered the most appropriate to its sustainability strategy. The transformational leadership style overcomes the limitations of both autocratic-bureaucratic system and authentic-consultative system (Adha et al. 2020). Thus, the hypothesis is formulated as follows:

Hypothesis 4 (H4). Transformational leadership style has a positive effect on sustainability performance.

The ability of organization to manage knowledge is an essential factor supporting the company's competitiveness. When improving its quality, the company also improves its competitiveness relying on knowledge-based competitiveness (Bloodgood 2019). Knowledge management is a function helping identify and managing the organizational knowledge for a long-term benefit (Mahdi et al. 2019; Darroch 2003). Knowledge management is an essential tool to create the organizational future, including efforts to ensure its sustainability. Knowledge management does not merely aim at using the low-cost production 
methods considering its ability in creating and developing the added value (Al Saifi 2015). There is urgently needed to manage knowledge more effectively in the global economy to gain the competitive value (Soniewicki and Paliszkiewicz 2019) by maintaining the organizational performance sustainability. Many researchers have claimed that the source of competitive advantage is knowledge assets (Mahdi et al. 2019; Torres et al. 2018; de Guimarães et al. 2018). The organization has obtained benefits by adopting or implementing the knowledge management practices (Al Saifi 2015; Iqbal et al. 2019; Koohang et al. 2017; Arsawan et al. 2021). Specifically, knowledge management helps organizations optimize their organizational performance (Alshawabkeh et al. 2020; Graha et al. 2019). Empirical studies show that knowledge management processes positively affect organizational performance (Birasnav 2014). Thus, the hypothesis is formulated as follows:

Hypothesis 5 (H5). Knowledge management has a positive effect on sustainability performance.

Organizational culture is a source of sustainable competitive advantage (Barney 1991). Previous studies have shown that organizational culture is a key to organizational effectiveness (Hartnell et al. 2011; Zheng et al. 2013). Previous researchers have validated four dimensions of a conducive organizational culture to organizational effectiveness: adaptability, consistency, engagement, and mission (Denison and Mishra 1989). The process of performance sustainability will be achieved faster if the organization implements knowledge management. The relationship between organizational culture and sustainable management processes allows individuals and organizations to receive the expected benefits (Al Saifi 2015), such as a sustainable competitive advantage (Birasnav 2014). Knowledge management is an organizational asset to generate new ideas and knowledge management helping achieve the sustainable organizational performance. Therefore, knowledge management plays a potential role in linking the organizational culture with sustainable performance. Thus, the hypothesis is formulated as follows:

Hypothesis 6 (H6). Knowledge management mediates the relationship between organizational culture and sustainability performance.

Transformational leadership style helps organizations implement knowledge management practices. Leadership style encourages knowledge acquisition to improve organizational performance (Gonzales and Kopp 2017; Koohang et al. 2017). The knowledge management process accelerates the transformational leadership style in directing the organizational members towards the sustainable performance (Birasnav 2014). Leadership style also improves performance through knowledge management process, considering leaders who frequently reward the organizational members. Therefore, knowledge management is a potential mediator between transformational leadership and organizational performance (Birasnav 2014). Thus, the hypothesis is formulated as follows:

Hypothesis 7 (H7). Knowledge management mediates the relationship between leadership style and sustainability performance.

Based on the literature reviews and hypothetical development, the conceptual framework is then presented in Figure 1. 


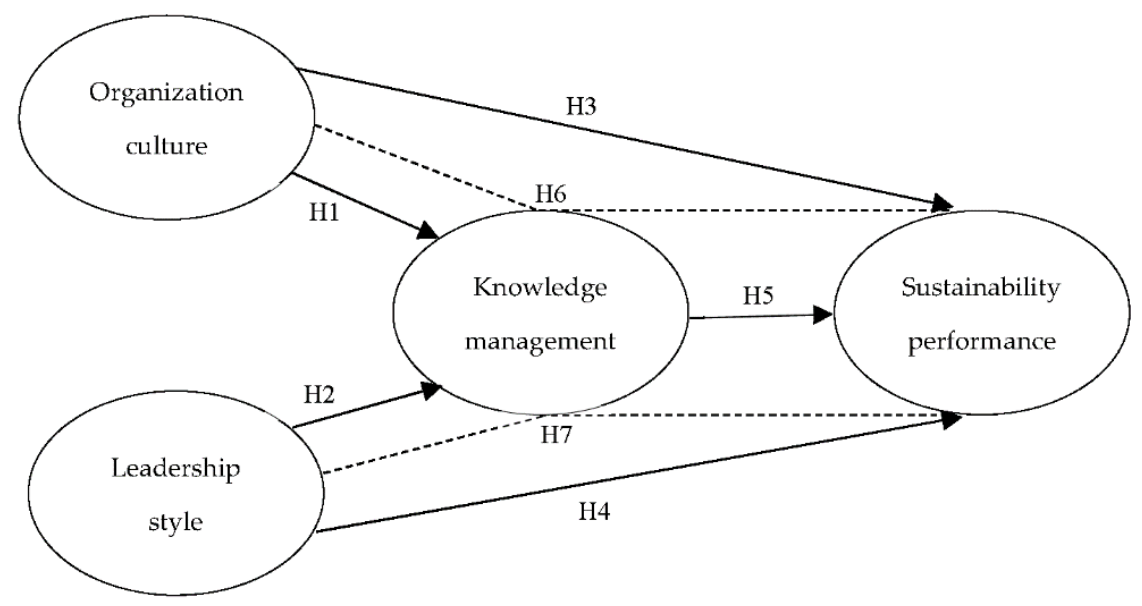

Figure 1. Conceptual framework.

\section{Methodology}

This study used a survey method. The data were collected using questionnaires distributed to farmers as the members of Subak organization in villages of Bali Province. Subak is a traditional organization based on a local Balinese cultural wisdom. UNESCO has nominated Subak as a Cultural Landscape of Bali: Subak as Manifestation of Tri Hita Karana philosophy (Windia 2013). Subak was selected as the research location because its existence has been eroded by modernization even though Subak is recognized as a world cultural heritage to preserve (Surata and Vipriyanti 2018). The management of Subak organization is based on an organizational culture rooted in the values of Tri Hita Karana philosophy. Tri Hita Karana is a traditional Balinese life philosophy emphasizing on harmony (Windia 2013). The synergy between leadership style, management knowledge, and organizational culture will maintain the sustainable performance of Subak organizations.

The population of this study was all members of four Subak organizations recognized by UNESCO covering Subak Jatiluwih Tabanan, Subak Pura Batur Bangli, Subak Tukad Pakerisan Gianyar, and Subak Mengwi Badung. A purposive sampling was performed based on specific considerations. There were three criteria used to determine the respondents: (1) Subak farmers as well as landowners, (2) already using technology, and (3) Subak organization established at least three years. Thus, the respondents meeting the research criteria were 99 people.

The exogenous research variables were knowledge management and sustainable performance, while the endogenous variables were organizational culture and transformational leadership. This study adapted the previous questionnaires relevant to the variables used in this research, particularly in the context of traditional organization. The questionnaires for the organizational culture variables were adapted from the previous studies (Denison et al. 2014; Denison and Mishra 1995; Sapta et al. 2016) using four indicators consisting of adaptability, consistency, involvement, and mission. The measurements for the transformational leadership style variables were adopted from the previous research (Afsar et al. 2019; Park and Kim 2018; Rai et al. 2019) consisting of four indicators covering individual consideration, idealized influence, inspirational motivation, and intellectual stimulation. The knowledge management variables were measured using five indicators consisting of localization, knowledge use, knowledge acquisition and development, knowledge codification, and knowledge transfer. The questionnaire was adopted from that developed by Koohang et al. (2017). The measurements used in the sustainability performance variable consisted of three dimensions covering economic performance, operational performance, and environmental performance. The measurement indicators were adapted from those developed by Yang et al. (2017). All questionnaires used 5 Likert scales ranging from scale 1 indicating "strongly disagree" to scale 5 indicating "strongly agree." This study used five options to ease respondents in distinguishing each scale point. The Likert scale ranging more significant than five is seen to be more difficult for respondents 
to choose an option. The odd (five) options have accommodated the respondents' needs to give neutral responses (Finstad 2010). In addition, this research used SEM-PLS to analyze the data.

\section{Results}

\subsection{Descriptive Statistics}

The research respondents were 99 people. The descriptive statistical calculations on the respondents' responses include mean, minimum and maximum value, and standard deviation presented in Table 1.

Table 1. Descriptive statistics.

\begin{tabular}{cccccc}
\hline Variable & N & Minimum & Maximum & Mean & Std. Deviation \\
\hline Organization culture & 99 & 8.00 & 20.00 & 16.06 & 3.10 \\
Leadership style & 99 & 8.00 & 20.00 & 15.94 & 3.35 \\
Knowledge management & 99 & 10.00 & 25.00 & 20.16 & 3.97 \\
Sustainability performance & 99 & 6.00 & 15.00 & 11.89 & 2.51 \\
Valid N (listwise) & 99 & - & - & - & - \\
\hline
\end{tabular}

Source: author calculation.

\subsection{Measurement Model Evaluation (Outer Model)}

Three criteria used to assess the outer model included convergent validity, discriminant validity, and composite reliability. Convergent validity testing aimed at measuring the indicator validity. The results were expressed through the values of outer loading factors. The values of outer model were said meeting the convergent validity if the loading factor value was greater than 0.50 . The loading factor values of indicators are presented in Table 2.

Table 2. Outer loading result.

\begin{tabular}{|c|c|c|}
\hline No & Variable & Outer Loading \\
\hline \multirow{5}{*}{1} & Organizational culture & - \\
\hline & Adaptability & 0.874 \\
\hline & Consistency & 0.920 \\
\hline & Involvement & 0.950 \\
\hline & Mission & 0.886 \\
\hline \multirow{5}{*}{2} & Transformational leadership & - \\
\hline & Individual consideration & 0.916 \\
\hline & Idealized influence & 0.905 \\
\hline & Inspirational motivation & 0.870 \\
\hline & Intellectual stimulation & 0.910 \\
\hline \multirow{6}{*}{3} & Knowledge management & - \\
\hline & Localization & 0.873 \\
\hline & Usage of knowledge & 0.916 \\
\hline & Knowledge acquisition and development & 0.945 \\
\hline & Knowledge codification & 0.821 \\
\hline & Knowledge transfer & 0.972 \\
\hline \multirow{4}{*}{4} & Sustainability performance & - \\
\hline & Economic performance & 0.956 \\
\hline & Operational performance & 0.936 \\
\hline & Environmental performance & 0.969 \\
\hline
\end{tabular}

Source: author calculation.

Table 2 shows that the outer model value measurements have met the convergent validity because the loading factor value was greater than 0.50 . This figure indicates that all research indicators were valid to form the four variables in this study. Thus, the outer loading value of each indicator has met the convergent validity requirements. 
The next step was examining the validity of discriminant indicators of a variable. This test compared the square root coefficient of average variance extracted ( $\sqrt{ } \mathrm{AVE}$ ) of each latent factor with the correlation coefficient in the model. The recommended AVE value in this study is 0.5 (Fornell and Larcker 1981). The results of discriminant validity testing are presented in Table 3.

Table 3. Discriminant validity.

\begin{tabular}{ccccccc}
\hline \multicolumn{1}{c}{ AVE } & \multicolumn{4}{c}{ Correlation } \\
\hline Variable & AVE & $\sqrt{ }$ AVE & $\begin{array}{c}\text { Knowledge } \\
\text { Management }\end{array}$ & $\begin{array}{c}\text { Leadership } \\
\text { Style }\end{array}$ & $\begin{array}{c}\text { Organizational } \\
\text { Culture }\end{array}$ & $\begin{array}{c}\text { Sustainability } \\
\text { Performance }\end{array}$ \\
\hline Knowledge management & 0.832 & 0.912 & 0.912 & - & - & - \\
Leadership style & 0.784 & 0.885 & 0.826 & 0.885 & - & - \\
Organization culture & 0.824 & 0.908 & 0.975 & 0.845 & 0.908 & 0.958 \\
Sustainability performance & 0.918 & 0.958 & 0.872 & 0.856 & 0.867 & - \\
\hline
\end{tabular}

Source: author calculation.

The discriminant validity test results in Table 3 show that the value of the average variance extracted (AVE) score was more significant than 0.05 . This result shows that the indicators representing the dimensions of variables in this study had good discriminant validity. Thus, the variables had sufficient discriminant validity.

Furthermore, this study examined the composite reliability. The results of variable reliability testing were measured with two criteria, consisting of Cronbach Alpha and composite reliability. The composite reliability value and Cronbach Alpha are presented in Tables 4 and 5 .

Table 4. Composite reliability.

\begin{tabular}{ccc}
\hline No & Variable & Composite Reliability \\
\hline 1 & Knowledge management & 0.929 \\
2 & Leadership style & 0.930 \\
3 & Organization culture & 0.899 \\
4 & Sustainability performance & 0.970 \\
\hline
\end{tabular}

Source: author calculation.

Table 5. Cronbach's Alpha.

\begin{tabular}{cccc}
\hline No & Variable & Cronbach's Alpha & Information \\
\hline 1 & Knowledge & 0.932 & Reliable \\
2 & management & 0.947 & Reliable \\
3 & Leadership style & 0.871 & Reliable \\
4 & Organization culture & 0.990 & Reliable \\
\hline
\end{tabular}

Source: author calculation.

Based on Table 4, the composite reliability value was 0.899-0.970 more significant than 0.7 exceeding the recommended value. Table 5 presents the Cronbach Alpha values ranging from 0.871 to 0.990 . Therefore, the variables of this study have met the reliable criteria. Thus, the indicators of this research were valid and reliable.

\subsection{Evaluation of the Structural Model (Inner Model)}

The structural model was evaluated using R-square. Each change in R-square value assessed certain exogenous latent variables on endogenous latent variables with a substantive effect. The results of R-square estimation are presented in Table 6. 
Table 6. R-Square Value.

\begin{tabular}{ccc}
\hline No & Variable & R-Square \\
\hline 1 & Knowledge management (Y1) & 0.715 \\
2 & Sustainability performance (Y2) & 0.853 \\
\hline
\end{tabular}

Source: author calculation.

In addition to R-square, the researchers also measured the goodness of fit model using Q-Square predictive relevance for the structural model. Q-square value of $>0$ indicated that the model had the predictive relevance; conversely, if the value of Q-Square is $=0$, it indicates that the model is lack of predictive relevance. The calculation of Q-Square is conducted using the formula:

$$
\begin{aligned}
\mathrm{Q}^{2} & =1-\left(1-\mathrm{R} 1^{2}\right)\left(1-\mathrm{R} 2^{2}\right) \\
& =1-(1-0.715)(1-0.853) \\
& =1-(0.285)(0.147) \\
& =1-0.042 \\
& =0.96
\end{aligned}
$$

The results of $Q$-Square predictive relevance $\left(Q^{2}\right)$ calculation show the value of 0.96 . The $\mathrm{Q}^{2}$ value could measure how well the model and its parameter estimations generate the observed value. The $\mathrm{Q}^{2}$ value which was greater than 0 (zero) indicates that the model was adequately good, while the $\mathrm{Q}^{2}$ value which was less than 0 (zero) indicates that the model had less predictive relevance. In this research model, the construct of endogenous latent variable had the $\mathrm{Q}^{2}$ value of 0.96 , greater than 0 (zero). Therefore, the predictions made by the model were considered relevant. The next test was to examine the formulated hypotheses. The results of the hypothetical testing are shown in Table 7.

Table 7. Hypotheses testing result.

\begin{tabular}{ccccc}
\hline Relationship between Variables & $\begin{array}{c}\text { Path Coefficient } \\
\text { (Bootstrapping) }\end{array}$ & t-Statistics & Sig & Decision \\
\hline Organization culture $\rightarrow$ knowledge management & 0.338 & 2.955 & $0.003^{*}$ & H1 accepted \\
Leadership style $\rightarrow$ knowledge management & 0.541 & 4.964 & $0.000^{*}$ & H2 accepted \\
Organization culture $\rightarrow$ sustainability performance & 0.365 & 2.884 & $0.004^{*}$ & $\mathrm{H}^{*}$ accepted \\
Leadership style $\rightarrow$ sustainability performance & 0.210 & 2.156 & $0.032^{*}$ & H4 accepted \\
Knowledge management $\rightarrow$ sustainability performance & 0.409 & 3.073 & $0.002^{*}$ & H5 accepted \\
\hline
\end{tabular}

* Statistically significant at $5 \%$ significance levels (two-sided $t$-test). Source: author calculation.

\section{Discussion}

The first hypothesis stated that organizational culture had a positive effect on knowledge management. The testing results show the t-statistical value of $2.955>1.96$ and significance value of $0.003<0.05$. Therefore, the first hypothesis was accepted. It can be concluded that organizational culture has a positive effect on knowledge management. Organizational culture is defined as values or symbols that the members of organization must understand. At the same time, the culture reflects the uniqueness between one organization and others - the importance of culture in managing the organizational knowledge. Culture is considered as a part of intangible structural capital facilitating the knowledge management implementation. Therefore, organizational culture facilitates knowledge management practices and improves the organizational performance (Ajmal and Helo 2010; Zheng et al. 2013; Adeinat and Abdulfatah 2019). Subak organizations have recently provided resources for place-based education and organizational members that become an integral part of all students' learning aspects (Surata and Vipriyanti 2018). These findings also implied that Tri Hita Karana was a traditional life philosophy in Bali supporting the knowledge management implementation in organizations. Thus, these testing results 
supported the previous studies revealing a positive relationship between organizational culture and knowledge management (Ajmal and Helo 2010; Sheikhalizadeh and Piralaiy 2017; Fernandes 2018).

The second hypothesis stated that leadership style had a positive effect on knowledge management. The results show the t-statistical value of $4.964>1.96$ and a significance value of $0.000<0.05$. The second hypothesis was accepted. Thus, leadership affects knowledge management. This study used transformational leadership representing the leaders' characters in Subak organizations. The transformational leadership theory suggests that leader's behaviors can accelerate the employee's innovative thinking to improve the employee and organizational performance (Feranita et al. 2020; Rustiarini et al. 2019). These results supported the previous findings mentioning that transformational leaders greatly influenced the implementation of knowledge management to improve organizational performance (Aragón-Correa et al. 2007; Colbert et al. 2008; Piccolo and Colquitt 2006; Birasnav 2014). In Subak organizations, transformational leaders always remind the organization members to make innovations to improve the quality of agricultural products, encourage the utilization of technology, and have the entrepreneurial or managerial abilities in marketing the agricultural products. The development of intensive scientific and technological advancements greatly impacts the formation of labor modern division (Lim et al. 2018) and provides new opportunities to produce the value-added agricultural products. Technology has become one of prerequisites for the inclusive environmental management (Hamdoun et al. 2018), including in Subak organizations.

The third hypothesis stated that organizational culture had a positive effect on performance sustainability. The results supported the third hypothesis with the $t$-statistical value of $2.884>1.96$ and a significance value of $0.004<0.05$. Based on this value, the organizational culture has a positive effect on performance sustainability. Organizational culture is one key to achieve the sustainable organizational performance. Organizational culture contains various internal attributes, such as organizational norms and values, formal policies, procedures, and management systems (Eccles et al. 2014). Organizations need to integrate these missions, values, norms, and strategies into organizational culture (Galpin et al. 2015). In Subak organizations, the organizational culture which was based on Tri Hita Karana has implemented the concept of sustainable performance. Previously studies have stated that sustainability performance is an organizational activity seeking to achieve a sustainability balance. One of the concepts derived from the sustainable performance is Triple Bottom Lines (Lozano et al. 2013). Consistent with the Triple Bottom Lines literature, Tri Hita Karana is a culture requiring harmony between humans and God, humans and other humans, as well as humans and environment (Surata and Vipriyanti 2018).

The fourth hypothesis stated that leadership style had a positive effect on performance sustainability. This result supported the fourth hypothesis. This result was indicated by the t-statistical value of $2.156>1.96$ and significance value of $0.032<0.05$. Thus, transformational leadership had a positive effect on performance sustainability. Transformational leadership is the right style to direct organizations to achieve their sustainable performance (Waldman and Siegel 2008). Business activities are not just an organic circle of people but also all organization members. The existence leader's motivation is one of basic prerequisites for organizational efficiency (Rustiarini et al. 2019; Koohang et al. 2017). An effective management team is essential to ensure an organization's sustainability and development (Gryshova et al. 2019). Transformational leadership can help establish the professional organizational members, particularly in the modern labor market (Diachok et al. 2020). In Subak organizations, transformational leaders always remind the members of organization to use the environmentally friendly technology (Komin and Sedana 2019), increase knowledge related to the preservation of natural resources (Roth 2014), and maintain the spirit of cooperation in maintaining the physical networks and Subak ritual activities (Surata et al. 2014). Therefore, the leadership style will direct the Subak organizations to achieve their sustainable performance. 
The fifth hypothesis stated that knowledge management had a positive effect on performance sustainability. The statistical tests results show the t-statistical value of $3.073>$ 1.96 and significance value of $0.002<0.05$. This value supported the fifth hypothesis. Thus, knowledge management had a positive effect on performance sustainability. Knowledge management can choose low-cost production methods and consider methods which are capable of creating and developing different value-added (Lange 2006). Organizational knowledge can improve the quality of employees and become the organizational competitive advantage (Arsawan et al. 2021). In Subak organizations, knowledge management had an important role in motivating Subak members to increase knowledge on agribusiness activities in the modernization era and use the environmentally friendly technology (Komin and Sedana 2019). Knowledge management practices were also essential to improve the functions of Subak institutions, such as accommodating production, distribution, and marketing activities. Thus, Subak organizations facilitate the economic activities of local communities to achieve their sustainable performance.

The next test was analyzing the mediating role of knowledge management variable (Y1) between organizational culture (X1) and performance sustainability (Y2). This study also examined the mediating role of knowledge management variable (Y1) between leadership style (X2) and performance sustainability (Y2). The hypothetical testing on the indirect effects is shown in Table 8.

Table 8. Results of testing for knowledge management mediation variables.

\begin{tabular}{ccccccc}
\hline \multirow{2}{*}{ No } & Relationship between & \multicolumn{5}{c}{ Effect } \\
\cline { 3 - 6 } \\
\cline { 3 - 6 } & Variables & (A) & (B) & (C) & Decision \\
\hline \multirow{2}{*}{1} & Organization culture $\rightarrow$ & 0.365 & 0.503 & 0.338 & 0.409 & Partial \\
& sustainability performance & $(\mathrm{Sig})$ & $(\mathrm{Sig})$ & $(\mathrm{Sig})$ & $(\mathrm{Sig})$ & Mediation \\
\multirow{2}{*}{2} & Leadership style $\rightarrow$ & 0.210 & 0.432 & 0.541 & 0.409 & Partial \\
& sustainability performance & $(\mathrm{Sig})$ & $(\mathrm{Sig})$ & $(\mathrm{Sig})$ & $(\mathrm{Sig})$ & Mediation \\
\hline
\end{tabular}

Source: author calculation.

The overall effects on each relationship of variables under study are presented in Table 9.

Table 9. Direct effect, indirect effect, and total effect.

\begin{tabular}{|c|c|c|c|c|c|}
\hline No & Relationship between Variables & $\begin{array}{l}\text { Direct } \\
\text { Effect }\end{array}$ & Indirect Effect & $\begin{array}{l}\text { Total } \\
\text { Effect }\end{array}$ & Sig \\
\hline 1 & $\begin{array}{l}\text { Organization culture }(\mathrm{X} 1) \rightarrow \\
\text { knowledge management }(\mathrm{Y} 1)\end{array}$ & 0.338 & - & 0.338 & 0.003 * \\
\hline 2 & $\begin{array}{c}\text { Leadership style }(\mathrm{X} 2) \rightarrow \\
\text { knowledge management }(\mathrm{Y} 1)\end{array}$ & 0.541 & - & 0.541 & 0.000 * \\
\hline 3 & $\begin{array}{c}\text { Organization culture }(\mathrm{X} 1) \rightarrow \\
\text { sustainability performance }(\mathrm{Y} 2)\end{array}$ & 0.365 & - & 0.365 & 0.004 * \\
\hline 4 & $\begin{array}{c}\text { Organization culture }(\mathrm{X} 1) \rightarrow \\
\text { knowledge management }(\mathrm{Y} 1) \rightarrow \\
\text { sustainability performance }(\mathrm{Y} 2)\end{array}$ & 0.365 & $\begin{array}{c}(0.338 \times 0.409)= \\
0.138\end{array}$ & 0.503 & 0.001 * \\
\hline 5 & $\begin{array}{l}\text { Leadership style }(\mathrm{X} 2) \rightarrow \\
\text { sustainability performance (Y2) }\end{array}$ & 0.210 & - & 0.210 & $0.032 *$ \\
\hline 6 & $\begin{array}{c}\text { Leadership style }(\mathrm{X} 2) \rightarrow \\
\text { knowledge management }(\mathrm{Y} 1) \rightarrow \\
\text { sustainability performance }(\mathrm{Y} 2)\end{array}$ & 0.210 & $\begin{array}{c}(0.541 \times 0.409)= \\
0.221\end{array}$ & 0.431 & 0.013 * \\
\hline 7 & $\begin{array}{l}\text { Knowledge management }(\mathrm{Y} 1) \rightarrow \\
\text { sustainability performance }(\mathrm{Y} 2)\end{array}$ & 0.409 & - & 0.409 & $0.002 *$ \\
\hline
\end{tabular}

Tables 8 and 9 show that knowledge management (Y1) mediated the relationship between organizational culture (X1) and performance sustainability (Y2) acting as a partial mediation. The testing results accepted the sixth hypothesis. These findings indicated that 
knowledge management facilitated organizational culture to direct the organization towards sustainable performance. Organizational culture, combined with knowledge management creates opportunities for organizational members to innovate, learn, and develop themselves to achieve sustainable performance (Yang et al. 2017; Surata and Vipriyanti 2018).

Tables 8 and 9 also show that knowledge management (Y1) mediated the relationship between leadership style (X2) and performance sustainability (Y2) as a partial mediation. Thus, the results of this test accepted the seventh hypothesis. This finding implied that knowledge management facilitated transformational leaders in managing resources to achieve sustainable performance. Knowledge personally increased individual working performance and directed organizations to achieve their sustainable performance (Arsawan et al. 2021). In the context of Subak organizations, knowledge management helped leaders motivate their members to increase their knowledge and competencies. The knowledge possessed by the members of organization will encourage them to utilize the agricultural technology, starting from production to post-harvest. The organizational members who have the entrepreneurial and managerial knowledge determine the market, selling price, and payment system. Knowledge management practices support the efforts made by the transformational leaders to achieve their sustainable performance. Thus, knowledge management mediated leadership style and sustainable performance.

\section{Conclusions}

This study investigated the role of knowledge management in mediating organizational culture and transformational leadership to sustainable performance. The results confirmed that the knowledge-based theory which implemented knowledge management practices leads organizations to achieve their sustainable performance. Knowledge management also had a potential role in linking organizational culture with sustainable performance. Likewise, knowledge management accelerated the transformational leadership style in directing the organizational members towards sustainable performance in the relationship of leadership style with sustainable performance. One surprising finding obtained from this study was that knowledge management did not completely play its role as a mediator. In traditional organizational management, organizational culture, and transformational leadership still become the main organizational activity drivers. Thus, the implementation of knowledge management model must be matched with the organizational missions, values, norms, and strategies.

This study had two limitations. First, this study only analyzed the concept of local organizational culture using Tri Hita Karana which can not to be generalized to the other local organizational cultures. This limitation then opens opportunities for researchers in the other areas to explore different organizational cultures. Second, this study was conducted at agricultural organizations in the developing countries with different knowledge management practices. Therefore, it is necessary to examine the knowledge management practices in agricultural organizations of the developed countries to better understand the results.

Author Contributions: Conceptualization, I.K.S.S. and N.W.R.; methodology, I.K.S.S.; software, I.N.L.; writing—original draft preparation, I.K.S.S.; writing—review and editing, N.W.R.; supervision, I.N.S.; project administration, I.N.L.; funding acquisition, I.K.S.S. All authors have read and agreed to the published version of the manuscript.

Funding: This research received no external funding.

Institutional Review Board Statement: Not applicable.

Informed Consent Statement: Not applicable.

Data Availability Statement: Data sharing not applicable.

Conflicts of Interest: The authors declare no conflict of interest. 


\section{References}

Abubakar, Abubakar Mohammed, Hamzah Elrehail, Maher Ahmad Alatailat, and Alev Elçi. 2019. Knowledge Management, Decision-Making Style, and Organizational Performance. Journal of Innovation E Knowledge 4: 104-14. [CrossRef]

Adeinat, Iman M., and Fatheia H. Abdulfatah. 2019. Organizational Culture and Knowledge Management Processes: Case Study in a Public University. VINE Journal of Information and Knowledge Management Systems 49: 35-53. [CrossRef]

Adha, Suhroji, Fairus Sintawati, Octoberry Julyanto, Ratih Ayu Wulandari, and Agus Purwanto. 2020. Leadership Style for Indonesian Public Health Center: Charismatic, Bureaucratic, Transactional, Transformational, Autocratic or Democratic? European Journal of Molecular E Clinical Medicine 7: 115-24. Available online: https:/ / ejmcm.com/article_1713_9c1e8218a0cbe5ba879b435b870c7014. pdf (accessed on 20 March 2021).

Afsar, Bilal, and Waheed Ali Umrani. 2020. Transformational Leadership and Innovative Work Behavior. European Journal of Innovation Management 23: 402-28. [CrossRef]

Afsar, Bilal, Mariam Masood, and Waheed Ali Umrani. 2019. The Role of Job Crafting and Knowledge Sharing on the Effect of Transformational Leadership on Innovative Work Behavior. Personnel Review 48: 1186-208. [CrossRef]

Ajmal, Mian M., and Kaj U. Koskinen. 2008. Knowledge Transfer in Project-Based Organizations: An Organizational Culture Perspective. Project Management Journal 39: 7-15. [CrossRef]

Ajmal, Mian M., and Petri Helo. 2010. Organisational Culture and Knowledge Management: An Empirical Study in Finnish Project-Based Companies. International Journal of Innovation and Learning 7: 331-44. [CrossRef]

Alshawabkeh, Rawan, Amani Abu Rumman, Lina Al-Abbadi, and Ayman Abu-Rumman. 2020. The Intervening Role of Ambidexterity in the Knowledge Management Project Success Connection. Problems and Perspectives in Management 18: 56. [CrossRef]

Anning-Dorson, Thomas. 2018. Innovation and Competitive Advantage Creation: The Role of Organisational Leadership in Service Firms from Emerging Markets. International Marketing Review 35: 580-600. [CrossRef]

Aragón-Correa, J. Alberto, Víctor J. García-Morales, and Eulogio Cordón-Pozo. 2007. Leadership and Organizational Learning's Role on Innovation and Performance: Lessons from Spain. Industrial Marketing Management 36: 349-59. [CrossRef]

Arsawan, I. Wayan Edi, Viktor Koval, Ismi Rajiani, Ni Wayan Rustiarini, Wayan Gede Supartha, and Ni Putu Santi Suryantini. 2021. Leveraging Knowledge Sharing and Innovation Culture into SME's Sustainable Competitive Advantage. International Journal of Productivity and Performance Management. [CrossRef]

Barney, Jay. 1991. Firm Resources and Sustained Competitive Advantage. Journal of Management 17: 99-120. [CrossRef]

Baumgartner, Rupert J. 2014. Managing Corporate Sustainability and CSR: A Conceptual Framework Combining Values, Strategies and Instruments Contributing to Sustainable Development. Corporate Social Responsibility and Environmental Management 21: 258-71. [CrossRef]

Baumgartner, Rupert J., and Romana Rauter. 2017. Strategic Perspectives of Corporate Sustainability Management to Develop a Sustainable Organization. Journal of Cleaner Production 140: 81-92. [CrossRef]

Bedford, Denise. 2013. A Case Study in Knowledge Management Education-Historical Challenges and Future Opportunities. Electronic Journal of Knowledge Management 11: 199-213. Available online: https:/ / academic-publishing.org/index.php/ejkm (accessed on 20 March 2021).

Birasnav, Muthuraj. 2014. Knowledge Management and Organizational Performance in the Service Industry: The Role of Transformational Leadership beyond the Effects of Transactional Leadership. Journal of Business Research 67: 1622-29. [CrossRef]

Bloodgood, James M. 2019. Knowledge Acquisition and Firm Competitiveness: The Role of Complements and Knowledge Source. Journal of Knowledge Management 23: 46-66. [CrossRef]

Bogoviz, Aleksei V., Leonid F. Malinovski, Tamara G. Stroiteleva, Maxim M. Sharamko, and Vera V. Dvoretskaya. 2019. Connection between Organizational Culture and Specifics of the Process of Decision Making in Modern Business Systems. In Specifics of Decision Making in Modern Business Systems. Bingley: Emerald Publishing Limited. [CrossRef]

Cano-Kollmann, Marcelo, John Cantwell, Thomas J. Hannigan, Ram Mudambi, and Jaeyong Song. 2016. Knowledge Connectivity: An Agenda for Innovation Research in International Business. Journal of International Business Studies 47: 255-62. [CrossRef]

Cavazotte, Flávia, Valter Moreno, and Jane Bernardo. 2013. Transformational Leaders and Work Performance: The Mediating Roles of Identification and Self-Efficacy. BAR-Brazilian Administration Review 10: 490-512. [CrossRef]

Chang, Christina Ling-hsing, and Tung-Ching Lin. 2015. The Role of Organizational Culture in the Knowledge Management Process. Journal of Knowledge Management 19: 433-55. [CrossRef]

Colbert, Amy E., Amy L. Kristof-Brown, Bret H. Bradley, and Murray R. Barrick. 2008. CEO Transformational Leadership: The Role of Goal Importance Congruence in Top Management Teams. Academy of Management Journal 51: 81-96. [CrossRef]

Darroch, Jenny. 2003. Developing a Measure of Knowledge Management Behaviors and Practices. Journal of Knowledge Management 7: 41-54. [CrossRef]

Denison, Daniel, Levi Nieminen, and Lindsey Kotrba. 2014. Diagnosing Organizational Cultures: A Conceptual and Empirical Review of Culture Effectiveness Surveys. European Journal of Work and Organizational Psychology 23: 145-61. [CrossRef]

Denison, Daniel R., and Aniel K. Mishra. 1989. Organizational Culture and Organizational Effectiveness: A Theory and Some Preliminary Empirical Evidence. In Academy of Management Proceedings. New York: Academy of Management, pp. 168-72. [CrossRef]

Denison, Daniel R., and Aneil K. Mishra. 1995. Toward a Theory of Organizational Culture and Effectiveness. Organization Science 6: 204-23. [CrossRef] 
Diachok, Nadiia, Nadiia Chernukha, Liudmyla Tokaruk, Iuliia Udovenko, and Mariana Mateeva Petrova. 2020. Practical-Oriented Concept as a Principle of Professional Education of the Future Professionals. International Journal of Higher Education 9: $272-82$. [CrossRef]

Donate, Mario J., and Jesús D. Sánchez de Pablo. 2015. The Role of Knowledge-Oriented Leadership in Knowledge Management Practices and Innovation. Journal of Business Research 68: 360-70. [CrossRef]

Dugan, John P. 2017. Leadership Theory: Cultivating Critical Perspectives. London: John Wiley \& Sons.

Eccles, Robert G., Ioannis Ioannou, and George Serafeim. 2014. The Impact of Corporate Sustainability on Organizational Processes and Performance. Management Science 60: 2835-57. [CrossRef]

Fairman, Janet C., and Sarah V. Mackenzie. 2015. How Teacher Leaders Influence Others and Understand Their Leadership. International Journal of Leadership in Education 18: 61-87. [CrossRef]

Farooq, Rayees. 2019. Developing a Conceptual Framework of Knowledge Management. International Journal of Innovation Science 11: 139-60. [CrossRef]

Feng, Jie, Yucheng Zhang, Xinmei Liu, Long Zhang, and Xiao Han. 2018. Just the Right Amount of Ethics Inspires Creativity: A Cross-Level Investigation of Ethical Leadership, Intrinsic Motivation, and Employee Creativity. Journal of Business Ethics 153: 645-58. [CrossRef]

Feng, Yunting, Qinghua Zhu, and Kee-Hung Lai. 2017. Corporate Social Responsibility for Supply Chain Management: A Literature Review and Bibliometric Analysis. Journal of Cleaner Production 158: 296-307. [CrossRef]

Feranita, Nungky Viana, Alifian Nugraha, and Andrean Sukoco Sampir. 2020. Effect of Transformational and Transactional Leadership on SMEs in Indonesia. Problems and Perspectives in Management 18: 415. [CrossRef]

Ferdig, Mary A. 2007. Sustainability Leadership: Co-Creating a Sustainable Future. Journal of Change Management 7: 25-35. [CrossRef]

Fernandes, Adji Achmad Rinaldo. 2018. The Effect of Organization Culture and Technology on Motivation, Knowledge Asset and Knowledge Management. International Journal of Law and Management 60: 1087-96. [CrossRef]

Finstad, Kraig. 2010. Response Interpolation and Scale Sensitivity: Evidence against 5-Point Scales. Journal of Usability Studies 5: 104-10. Available online: http://www.uxpajournal.org/wp-content/uploads/pdf/JUS_Finstad_May_2010.pdf (accessed on 22 February 2021).

Fornell, Claes, and David F. Larcker. 1981. Evaluating Structural Equation Models with Unobservable Variables and Measurement Error. Journal of Marketing Research 18: 39-50. [CrossRef]

Galpin, Timothy, J. Lee Whitttington, and Greg Bell. 2015. Is Your Sustainability Strategy Sustainable? Creating a Culture of Sustainability. Corporate Governance 15: 1-17. [CrossRef]

Gonzales, George, and Lori Kopp. 2017. The Use of Personality Traits to Predict Propensity to Commit Fraud. Journal of Forensic E Investigative Accounting 9: 979-1005.

Graha, Andi Nu, Achmad Sudiro, Armanu Armanu, and Kusuma Ratnawati. 2019. The Role of Knowledge Management in Organizational Performance: Case Study of University of Malang, Indonesia. Problems and Perspectives in Management 17: 230-43. [CrossRef]

Gryshova, Inna, Mariana Petrova, Milena Tepavicharova, Aleksey Petrovich Diachenko, and Tatiana Gutsul. 2019. A Model for Selection of a Management Team to Ensure the Sustainability and Development of the Business Organizations. Entrepreneurship and Sustainability Issues 7: 690-703. [CrossRef]

Gu, Qiannong, Thawatchai Jitpaipoon, and Jie Yang. 2017. The Impact of Information Integration on Financial Performance: A Knowledge-Based View. International Journal of Production Economics 191: 221-32. [CrossRef]

de Guimarães, Julio Cesar Ferro, Eliana Andrea Severo, and César Ricardo Maia de Vasconcelos. 2018. The Influence of Entrepreneurial, Market, Knowledge Management Orientations on Cleaner Production and the Sustainable Competitive Advantage. Journal of Cleaner Production 174: 1653-63. [CrossRef]

Hamdoun, Mohamed, Charbel Jose Chiappetta Jabbour, and Hanen Ben Othman. 2018. Knowledge Transfer and Organizational Innovation: Impacts of Quality and Environmental Management. Journal of Cleaner Production 193: 759-70. [CrossRef]

Hartnell, Chad A., Amy Yi Ou, and Angelo Kinicki. 2011. Organizational Culture and Organizational Effectiveness: A Meta-Analytic Investigation of the Competing Values Framework's Theoretical Suppositions. Journal of Applied Psychology 96: 677. [CrossRef]

Heisig, Peter, Olunifesi Adekunle Suraj, Aino Kianto, Cosmas Kemboi, Gregorio Perez Arrau, and Nasser Fathi Easa. 2016. Knowledge Management and Business Performance: Global Experts' Views on Future Research Needs. Journal of Knowledge Management 20: 1169-98. [CrossRef]

Hofstede, Geert. 2001. Culture's Recent Consequences: Using Dimension Scores in Theory and Research. International Journal of Cross Cultural Management 1: 11-17. [CrossRef]

Huang, Kuo-Feng, Romano Dyerson, Lei-Yu Wu, and G. Harindranath. 2015. From Temporary Competitive Advantage to Sustainable Competitive Advantage. British Journal of Management 26: 617-36. [CrossRef]

Hunter, John E. 2017. A Causal Analysis of Cognitive Ability, Job Knowledge, Job Performance, and Supervisor Ratings. In Performance Measurement and Theory. London: Taylor \& Francis. [CrossRef]

Ikeda, Kazuaki, and Anthony Marshall. 2016. How Successful Organizations Drive Innovation. Strategy E Leadership 44: 9-19. [CrossRef]

Iqbal, Amjad, Fawad Latif, Frederic Marimon, Umar Farooq Sahibzada, and Saddam Hussain. 2019. From Knowledge Management to Organizational Performance. Journal of Enterprise Information Management 32: 36-59. [CrossRef] 
Islam, Md Anwarul, Naresh Kumar Agarwal, and Mitsuru Ikeda. 2017. Effect of Knowledge Management on Service Innovation in Academic Libraries. IFLA Journal 43: 266-81. [CrossRef]

Jabbour, Charbel José Chiappetta, and Ana Beatriz Lopes de Sousa Jabbour. 2016. Green Human Resource Management and Green Supply Chain Management: Linking Two Emerging Agendas. Journal of Cleaner Production 112: 1824-33. [CrossRef]

Jennex, Murray E. 2015. Knowledge Management. Wiley Encyclopedia of Management. Major Reference Works. New Jersey: Wiley Online Library. [CrossRef]

Jiang, Weiping, Xianbo Zhao, and Jiongbin Ni. 2017. The Impact of Transformational Leadership on Employee Sustainable Performance: The Mediating Role of Organizational Citizenship Behavior. Sustainability 9: 1567. [CrossRef]

Jiménez, Sergio Ochoa, Gimena V. Cervantes Hurtado, Carlos A. Jacobo Hernández, and José G. Flores López. 2020. Knowledge and Innovation in Mexican Agricultural organizations. Economies 8: 103. [CrossRef]

Kark, Ronit, Dina Van Dijk, and Dana Rachel Vashdi. 2018. Motivated or Demotivated to Be Creative: The Role of Self-Regulatory Focus in Transformational and Transactional Leadership Processes. Applied Psychology 67: 186-224. [CrossRef]

Kengatharan, Navaneethakrishnan. 2019. A Knowledge-Based Theory of the Firm. International Journal of Manpower 40: 1056-74. [CrossRef]

Kianto, Aino, Josune Sáenz, and Nekane Aramburu. 2017. Knowledge-Based Human Resource Management Practices, Intellectual Capital, and Innovation. Journal of Business Research 81: 11-20. [CrossRef]

Kieninger, Pia R., Eiji Yamaji, and Marianne Penker. 2011. Urban People as Paddy Farmers: The Japanese Tanada Ownership System Discussed from a European Perspective. Renewable Agriculture and Food Systems 26: 328-41. Available online: https: //www.jstor.org/stable/44490645 (accessed on 22 February 2021). [CrossRef]

Komin, Wichaya, and Gede Sedana. 2019. Sustainable Agricultural Technologies on Rice Farming: Case of Subaks' in Bali Province, Indonesia. Journal of Sustainable Development Science 1: 18-26. [CrossRef]

Koohang, Alex, Joanna Paliszkiewicz, and Jerzy Goluchowski. 2017. The Impact of Leadership on Trust, Knowledge Management, and Organizational Performance. Industrial Management \& Data Systems 117: 521-37. [CrossRef]

Lange, Thomas. 2006. The Creation and Management of Knowledge: What Can We Learn from Applying the Principles of Economics? International Journal of Knowledge Management Studies 1: 7-17. [CrossRef]

Lee, Jung Chieh, Yih Chearng Shiue, and Chung Yang Chen. 2016. Examining the Impacts of Organizational Culture and Top Management Support of Knowledge Sharing on the Success of Software Process Improvement. Computers in Human Behavior 54: 462-74. [CrossRef]

Lim, Chiehyeon, Ki-Hun Kim, Min-Jun Kim, Jun-Yeon Heo, Kwang-Jae Kim, and Paul P. Maglio. 2018. From Data to Value: A Nine-Factor Framework for Data-Based Value Creation in Information-Intensive Services. International Journal of Information Management 39: 121-35. [CrossRef]

Linnenluecke, Martina K., and Andrew Griffiths. 2010. Corporate Sustainability and Organizational Culture. Journal of World Business 45: 357-66. [CrossRef]

Lopes, Cátia Milena, Annibal Scavarda, Luiz Fernando Hofmeister, Antônio Márcio Tavares Thomé, and Guilherme Luís Roehe Vaccaro. 2017. An Analysis of the Interplay between Organizational Sustainability, Knowledge Management, and Open Innovation. Journal of Cleaner Production 142: 476-88. [CrossRef]

Lozano, Rodrigo, Rebeka Lukman, Francisco J. Lozano, Donald Huisingh, and Wim Lambrechts. 2013. Declarations for Sustainability in Higher Education: Becoming Better Leaders, through Addressing the University System. Journal of Cleaner Production 48: 10-19. [CrossRef]

Mahdi, Omar Rabeea, Islam A. Nassar, and Mahmoud Khalid Almsafir. 2019. Knowledge Management Processes and Sustainable Competitive Advantage: An Empirical Examination in Private Universities. Journal of Business Research 94: 320-34. [CrossRef]

Matinaro, Ville, and Yang Liu. 2017. Towards Increased Innovativeness and Sustainability through Organizational Culture: A Case Study of a Finnish Construction Business. Journal of Cleaner Production 142: 3184-93. [CrossRef]

Nonaka, Ikujirō, and Hirotaka Takeuchi. 2007. The Knowledge-Creating Company. Harvard Business Review 85: 162. Available online: https:/ / memberfiles.freewebs.com/84/90/65819084/documents/TheKnowledge-CreatingCompany.pdf (accessed on 22 February 2021).

Nonaka, Ikujiro, and Ryoko Toyama. 2015. The Knowledge-Creating Theory Revisited: Knowledge Creation as a Synthesizing Process. In The Essentials of Knowledge Management. New York: Springer, pp. 95-110. [CrossRef]

Nurkholis, Nurkholis, Muh Dularif, and Ni Wayan Rustiarini. 2020. Tax Evasion and Service-Trust Paradigm: A Meta-Analysis. Cogent Business \& Management 7: 1-20. [CrossRef]

Obeidat, Bader Yousef, Mai Maher Al-Suradi, and Ali Tarhini. 2016. The Impact of Knowledge Management on Innovation. Management Research Review 39: 1214-38. [CrossRef]

Omotayo, Funmilola Olubunmi. 2015. Knowledge Management as an Important Tool in Organisational Management: A Review of Literature. Library Philosophy and Practice 1: 1-23. Available online: http:/ / digitalcommons.unl.edu/libphilprac (accessed on 22 February 2021).

Park, Sunyoung, and Eun Jee Kim. 2018. Fostering Organizational Learning through Leadership and Knowledge Sharing. Journal of Knowledge Management 22: 1408-23. [CrossRef]

Parkin, Sara. 2010. The Positive Deviant: Sustainability Leadership in A Perverse World. London: Routledge. 
Piccolo, Ronald F., and Jason A. Colquitt. 2006. Transformational Leadership and Job Behaviors: The Mediating Role of Core Job Characteristics. Academy of Management Journal 49: 327-40. [CrossRef]

Rai, Kamini, Shikha Dua, and Miklesh Yadav. 2019. Association of Financial Attitude, Financial Behaviour, and Financial Knowledge towards Financial Literacy: A Structural Equation Modeling Approach. FIIB Business Review 8: 51-60. [CrossRef]

Rasula, Jelena, Vesna Bosilj Vuksic, and Mojca Indihar Stemberger. 2012. The Impact of Knowledge Management on Organisational Performance. Economic and Business Review for Central and South-Eastern Europe 14: 147-68. Available online: https://search. proquest.com/openview /2c8c6c703ef4afcacb70d81b74c99cec/1?pq-origsite=gscholar\&cbl=44642 (accessed on 22 February 2021).

Robbins, Stephen P., and Timothy A. Judge. 2016. Organizational Behavior, 16th ed. London: Pearson.

Roth, Dik. 2014. Environmental Sustainability and Legal Plurality in Irrigation: The Balinese Subak. Current Opinion in Environmental Sustainability 11: 1-9. [CrossRef]

Roth, Dik, and Gede Sedana. 2015. Reframing Tri Hita Karana: From ‘Balinese Culture' to Politics. The Asia Pacific Journal of Anthropology 16: 157-75. [CrossRef]

Rustiarini, Ni Wayan, Sutrisno Sutrisno, Nurkholis Nurkholis, and Wuryan Andayani. 2019. Why People Commit Public Procurement Fraud? The Fraud Diamond View. Journal of Public Procurement 19: 345-62. [CrossRef]

Al Saifi, Said Abdullah. 2015. Positioning Organisational Culture in Knowledge Management Research. Journal of Knowledge Management 19: 164-89. [CrossRef]

Sapta, Ketut Setia, Wayan Gde Supartha, Gde Riana, and Made Subudi. 2016. The Role of Organizational Commitment on Mediating the Relationship between Leadership and Tri Hita Karana Culture with Subak Performance in Bali. European Journal of Business and Management 8: 105-19. Available online: https://core.ac.uk/download/pdf/234627499.pdf (accessed on 20 March 2021).

Schaltegger, Stefan, Erik G. Hansen, and Florian Lüdeke-Freund. 2015. Business Models for Sustainability: Origins, Present Research, and Future Avenues. Organization E Environment 29: 3-10. [CrossRef]

Sheikhalizadeh, Mahboub, and Elaheh Piralaiy. 2017. The Effects of Organizational Culture on University's Academic Staff Knowledge Management. MOJEM: Malaysian Online Journal of Educational Management 4: 17-31. [CrossRef]

Soniewicki, Marcin, and Joanna Paliszkiewicz. 2019. The Importance of Knowledge Management Processes for the Creation of Competitive Advantage by Companies of Varying Size. Entrepreneurial Business and Economics Review 7: 43-63. [CrossRef]

Stankevičiūtė, Živilè, and Asta Savanevičienè. 2021. Linkage between Leaders' Behaviour in Performance Management, Organisational Justice, and Work Engagement in Public Sector. Economies 9: 15. [CrossRef]

Stehr, Nico. 1992. Practical Knowledge Applying The Social Sciences. London: Sage Publication.

Surata, Sang Putu Kaler, and Nyoman Utari Vipriyanti. 2018. The Subak Cultural Landscape as Environmental Education: Knowledge, Attitudes, and Experiences of Balinese Teachers, Student Teachers, and Students. The Journal of Environmental Education 49: 59-70. [CrossRef]

Surata, Sang Putu Kaler, Gars Jayantini, and John Stephen Lansing. 2014. Exploring Community Capital of the Balinese Subak Cultural Heritage: A Content Analysis of Participatory Maps. International Journal of Technical Research and Applications 2: 28-34.

Torres, Ana Isabel, Silvana Santos Ferraz, and Helena Santos-Rodrigues. 2018. The Impact of Knowledge Management Factors in Organizational Sustainable Competitive Advantage. Journal of Intellectual Capital 19: 453-72. [CrossRef]

Tseng, Ming-Lang, Ming K. Lim, and Kuo-Jui Wu. 2018. Corporate Sustainability Performance Improvement Using an Interrelationship Hierarchical Model Approach. Business Strategy and the Environment 27: 1334-46. [CrossRef]

Valmohammadi, Changiz, and Mohsen Ahmadi. 2015. The Impact of Knowledge Management Practices on Organizational Performance. Journal of Enterprise Information Management 28: 131-59. [CrossRef]

Valmohammadi, Changiz, Javad Sofiyabadi, and Bahare Kolahi. 2019. How Do Knowledge Management Practices Affect Sustainable Balanced Performance? Mediating Role of Innovation Practices. Sustainability 11: 5129. [CrossRef]

Waldman, David A., and Donald Siegel. 2008. Defining the Socially Responsible Leader. The Leadership Quarterly 19: 117-31. [CrossRef] Wiguna, Iwaa, and Sang Putu Kaler Surata. 2008. Multifungsi Ekosistem Subak Dalam Pembangunan Pariwisata Di Bali. Yogyakarta: Aksara Indonesia.

Windia, Wayan. 2013. Strengthening Subak Culture through Empowerment of Farmers. Journal of Bali Studies 3: 137-58.

Yadav, Mohit, Sangita Choudhary, and Shubhi Jain. 2019. Transformational Leadership and Knowledge Sharing Behavior in Freelancers: A Moderated Mediation Model with Employee Engagement and Social Support. Journal of Global Operations and Strategic Sourcing 12: 202-24. [CrossRef]

Yahaya, Rusliza, and Fawzy Ebrahim. 2016. Leadership Styles and Organizational Commitment: Literature Review. Journal of Management Development 35: 190-216. [CrossRef]

Yang, Zhaojun, Jun Sun, Yali Zhang, and Ying Wang. 2017. Green, Green, It's Green: A Triad Model of Technology, Culture, and Innovation for Corporate Sustainability. Sustainability 9: 1369. [CrossRef]

Zheng, Wei, Baiyin Yang, and Gary N. McLean. 2013. Linking Organizational Culture, Structure, Strategy, and Organizational Effectiveness: Mediating Role of Knowledge Management. Journal of Business Research 63: 763-71. [CrossRef] 